\title{
THE PHRENIC REFLEX IN EPIDURAL ANALGESIA
}

\section{P. R. Bromage, M B , B.S., F.F.A.R.C.S ${ }^{1}$}

AN ALTERATION of certain respuratory reflex patterns appears to accompany high subarachnoid or extradural spinal blockade. Attention has been drawn to the 1elease of bronchospasm which often occurs in bronchospastic patients after induction of a high epidural block (1), and it has been shown that the vital capacity may merease by over 30 per cent in these patients (2).

In addition to release of bronchospasm, a modification of the diaphragmatic reflex also occurs I noticed that in thoraco-abdominal operations carried out under a combination of a light general anaesthesia and epidural block to $T_{2}$, the draphragm would remam unreactive even though the surgical incision extended to the central part of the diaphragm. Fallure to respond to direct diaphragmatic stimulation in the presence of an intact reflex arc (through $\mathrm{C}_{3}, \mathrm{C}_{4}$ and $\mathrm{C}_{5}$ ), invited closer attention, and this paper is concerned with further clinical observations on the phenomenon of associated phrenic suppression.

\section{METHOD}

Fufty-two patients undergoing thoracotomy were anaesthetzzed by a combination of contunuous epidural analgesia and light general anaesthesia in such a way that aurway control could be assured throughout the operation, while at the same time anaesthesia was light enough to determine the upper level of segmental analgesia with fair accuracy. The upper level of analgesia was tested by pinprick or pinching the skin after induction of the epidural block and during and immediately after operation. The following segmental landmarks were adopted, compromising between the dermatome maps of Foerster (3) and Keegan (4):

$\mathrm{T}_{4}$ Fourth intercostal space in axullary line

$\mathrm{T}_{3}$ Thurd intercostal space in axillary line

$T_{2}$ Skin of thoracic wall of axilla

$\mathrm{T}_{1}$ Skm of unner side of upper arm above elbow

$\mathrm{C}_{8}$ Ulnar border of forearm and little finger

$\mathrm{C}_{7}$ Not tested owing to possibilty of overlap between $\mathrm{C}_{6}$ and $\mathrm{C}_{8}$

$\mathrm{C}_{6}$ Thumb and radial border of forearm

During the course of operation, the surgeon was asked to stimulate the central portion of the diaphragm by pinching with a haemostat, and then to stimulate the phrenic nerve by light pinching while any associated movements of the diaphragm were observed

\section{Anaesthetic Procedure}

Premedication was moderately heavy, usually with Pentobarbital $100 \mathrm{mg}$. two hours before operation, followed by Demerol, 50 to $100 \mathrm{mg}$., and atropine, $0.4 \mathrm{mg}$,

1Department of Anaesthesid, McGill University and Royal Victoria Hospital, Montreal.

2Dosage for lidocaine $(\mathrm{ml})=$. [Height in inches $+10 \%+3$ times the number of spinal segments to be blocked above the vertebral level of injection] - [(Age in years $\div 3)+47]$ $\times 0.6(1$, p. 81$)$. 
one hour before operation. An epidural catheter was inserted in any convenient space between $T_{10}$ and $L_{3}$, and analgesia induced with lidocaine (Xylocame), 1.5 per cent without adrenaline. Dosage was based on a formula for the dosage of $1 / 600$ nupercaine, reduced by a factor of $\times 0.6$ to allow for the extra spreading tendencies of lidocaine (1). ${ }^{2}$ Any fall of blood pressure was, corrected by small doses of d-methyl amphetamine (Methedrine). Twelve to twenty minutes later the upper level of skin analgesia was tested by pin-prick. The level of the epidural block was maintained by giving half the volume of the mitial dose every fifty to sixty minutes.

The laryngeal and tracheal reflexes were obtunded by a transtracheal injection of $2-3 \mathrm{ml}$. of 4 per cent lidocaine, and anaesthetic sleep induced with 2.5 per cent thiopental. Before and durng induction of anaesthesia the patient was instructed to relax his face and neck muscles; this was of considerable helo in providing relaxation of the jaw without the aid of a muscle relaxant for trac_eal intubation. At this point bronchoscopy and endobronchial intubation were carried out if indicated by the nature of the pulmonary lesion. A cuffed endotracheal tube was gently inserted, and light anaesthesia mantained with five litres of nitrous oxide and two litres of oxygen per minute with $\mathrm{CO}_{2}$ absorption. Further increments of thiopental were given, if necessary, to keep the patient from moving his head and arms durng the operation. Controlled apnoea was induced by gentle hyperventilation, and under these circumstances the patient usually surrendered his spontaneous respiratory rhythm after five or ten "squeezes" of the respiratory bag. Minute volumes of 12-15 litres per minute were imposed. When a mechanical respirator was used the setting of the inspuratory pressure phase and the respiratory rate were determined by carrying out a few complance readings before the start of operation. These were done by measuring the expuratory volume over an inspiratory pressure range of $10-20 \mathrm{~cm} . \mathrm{H}_{2} \mathrm{O}$. Towards the end of operation epidural analgesia was maintaned with a 0.8 per cent lidocaine solution instead of the 1.5 per cent solution to ensure that there would be minimal intercostal motor depression in the early postoperative period. The patients were awakened at the end of operation just before the skin sutures were completed, and the upper level of analgesia again checked.

A control series was attempted in eight other cases using the same general anaesthetic technique, but omitting the epidural block. The results were unsatisfactory. Respiration became uncontrollable, and a muscle relaxant had to be given to subdue the patients. In a few others a muscle relaxant was given at the outset, and the effect allowed to wear off when the chest was open. Diaphragmatic movements returned in these patients also and operating conditions became intolerable, requiring further increments of muscle relaxant.

\section{Results}

Anaesthesia was remarkably smooth. Patients with existing bronchospasm showed improvement after the block.

Once apnoea was imposed by hyperventilation, the diaphragm remained relaxed and tranquil despite being rubbed, cut or stitched. Stimulation of the 
central portion by pinc.zing with a haemostat elicited only a localized slu zgish fasciculation, but no co-ordinated contraction. On the other hand, stimu ation of the phrenic nerve did elicit a fully co-ordinated contraction.

Owing to the exigencies of a busy operating theatre it was not possible to obtain accurate sensory levels in more than 310 the 52 patients. The distribution of these levels is shown below.

$\begin{array}{cc}\text { Upper analgesic dermatome } & \text { No. of cases } \\ \mathrm{C}_{6} & 3 \\ \mathrm{C}_{7} & - \\ \mathrm{C}_{8} & 5 \\ \mathrm{~T}_{1} & 8 \\ \mathrm{~T}_{2} & 10 \\ \mathrm{~T}_{3} & 4 \\ \mathrm{~T}_{4} & 1\end{array}$

It is probable that most of the remaining cases showed a similar sort of distribution, and certainly none were found to have analgesia extending as high as $\mathrm{C}_{4}$.

\section{DisCussion}

The observations on the behaviour of the diaphragm require interpretation and explanation, since it is not immediately apparent why the diaphragm should remain tranquil when the central portion is stimulated in the presence of an intact reflex arc mediated through the phrenic roots of $\mathrm{C}_{3}, \mathrm{C}_{4}$ and $\mathrm{C}_{5}$. For although a block to $T_{2}$ will effectively interrupt sensations travelling in the dorsal roots of the lower six or seven intercostal nerves from the periphery of the diaphragm, the phrenic roots remain untouched.

If we concede that the sensory levels shown above were observed accurately, and that anaesthesia did not extend higher than $\mathrm{C}_{8}$ in most cases, then two possibilities exist: (1) the innervation of the diaphragm is not so clear cut as is commonly believed; or (2) a functional reciprocation exists between the reflex patterns of the chest wall and those of the diaphragm of such delicate balance that suppression of the one is followed by suspression of the other.

The segmental motor supply of the diaparagm can vary within fairly wide limits. Kuré claimed that sympathetic efferents were partly responsible for diaphragmatic tone (5), but more recent work leaves little doubt that the motor supply is entrely confined to the spinal outflow from the phrenic nucleus (6). The commonest site of the phrenic motor nucleus is $\mathrm{C}_{3}, \mathrm{C}_{4}$ and $\mathrm{C}_{5}$, but occasionally fibres may arise from any segment between $C_{1}$ and $T_{1},(8,9,10)$. Therefore, some degree of phrenic impairment might be expected in a small proportion of patents receiving a spinal block to $\mathrm{C}_{6}$. However, in this series few of the blocks extended above $\mathrm{C}_{8}$, and so it is unlikely that partial motor block of the phrenic nerve could have accounted for the observed diaphragmatic immobility during thoracotomy. Moreover, spontaneous diaphragmatic respiration was unimpaired except when apnoea was imposed by hyperventilation.

Since the motor side of the diaphragmatic reflex arc was not interrupted, it follows that diaphragmatic immobility must have been due to depression of either the afferent or the central components of the phrenic reflex arc. However, 
there appeared to be little central depression of reflexes from other areas above the upper level of analgesia, since anaesthesia was so light that pinching the skin over the neck and shoulder would elicit a grimace or movements of the hand, so it may be assumed that the central components of the phrenic reflex were equally unaffected by the depth of anaesthesia. The unsatisfactory anaesthetic conditions in the control cases confirms that the combination of narcosis and hyperventilation did not produce sufficient central respiratory depression to abolish spontaneous diaphragmatıc activity

The afferent side of the phrenic reflex arc remains to be considered. About one-thurd of the fibres running in the phrenic nerve are sensory, the proportion of unmyelmated to myelnated sensory fibres being unusually high compared with other motor nerves (11). The reason for this unusual proportion is not clear, although a partial explanation may lie in the presence of a certain number of unmyelinated sympathetic afferents which travel with the phrenc nerve for varying distances (12). Cerebrospinal afferents reach the phrenic nucleus through the dorsal roots of $\mathrm{C}_{3}, \mathrm{C}_{4}$ and $\mathrm{C}_{5}$ as well as $\mathrm{C}_{6}(13)$, but these, like the motor outtlow, would have been above the level of epidural block, although under the circumstances their influence proved meffective

Other afferents whose branches could play upon the phrenic nucleus in thein passage to the bram stem would include sensory fibres from the thoracre wall and visceral afferents from the lungs, chest and abdomen These latter appear to have some influence on diaphragmatic contraction, and Cromer and Ivy claim that their section reduces diaphragmatic tone (14). It is these sensory components which are eliminated by the type of block used in this investugation

From the above evidence, one is led to the conclusion that phrenic reflex activity is normally dependent upon the summation of a number of different sensory stimul, and that depletion of part of the total afferent neuronal "pool" leads to depression of the phrenic spinal reflex. Normally this neuronal "pool" will be fed by contributions from the upper sympathetic rami carrying impulses trom the lungs and thoracic wall $(15,16,17)$, together with cerebrospinal afferents from the thoracic cage. The effect of these is magnified because they act on the phrenic nucleus in two stages, directly, and by long projection pathways through the respiratory centre. Thus their elimination will have a correspondingly exaggerated effect in raising the threshold of the phrenic nucleus to such a level that the remaining incoming pathways cannot carry a sufficient volume of stimulı to produce a motor response.

For reasons of simplacity the phrenic reflex has been regarded in isolation from other related effects produced by high spinal block. Among these, modification of broncho-motor reflexes are of prime importance in the total picture of anaesthetic tranquillity and their study will form the subject of a separate communcation

\section{SUMMARY}

Reflex response to stimulation of the central portion of the diaphragm is abolished by light general anaesthesia and epidural blockade to a level below CThe reasons for this are discussed. 


\section{RÉSUMÉ}

Cinquante-deux malades ont subı une thoracotomie sous anesthésie épidurale lombaire, combinée à une anesthésie générale superficielle, utlisant du pentothal, du protoxyde d'azote et de l'oxygène par voie endotrachéale. L'analgésie épidurale fut administrée à l'ande d'une solution de Xylocaine à $1.5 \%$ à travers une sonde en matière plastique (vinyl), insérée dans un espace interépmeux approprié entre $T_{10}$ et $\mathrm{L}_{3}$. La limite supérieure de l'analgésie fut maintenue entre $\mathrm{C}_{6}$ et $\mathrm{T}_{4}$, afin d'épargner les racines mortices et sensituves du nerf phrénique et de conserver ansi une mobilité duaphragmatıque normale et spontanée 'L'apnée fut obtenue par hyperventilation.

En de parelles circonstances la region pérphérnque du diaphragme est insensibilssée, la région centrale par contre (innervée par les trossième, quatrième et conquième nerfs cervicaux) garde sa sensibilité et réagit 'à l'excitation directe Cependant une excitation directe de la région centrale du diaphragme durant lopération ne réussit pas à déclencher une contraction coordonnée, quoıque la stimulation du nerf phrénique lui-même y parvenait facılement. Une sériecontrôle sous anésthesie générale superficielle, mais sans bloc épıdural, répondit par une contraction extrèmement vigoureuse a l'excitation de la région centrale du draphragme

Afin d'explqquer les observations sus-jacentes, l'hypothèse suivante est émıse.

Le réflexe phrénique est déclenché par la somme de différentes excitations pérıhérıques, réalısant une sorte de "pool" nerveux. Toute dimmution d'un affluent, alımentant ce "pool," entraîne une dépression de réflexe draphragmatıque, puisque le seul de contraction ne peut plus être atteint. Le "pool" nerveux est normalement alımenté par des apports formés des ramfications sympathiques supérieures, transmettant les excitations des poumons et de la cage thoracique, ainsı qué des fibres médullaires afférentes de la cage thoracıque et de la plèvre pariétale. Quand les excitations périphériques, transmıses par ces nerfs, sont abolies par une anesthésie épidurale haute, le seul de contraction diaphragmatique ne pourra plus être atteint à l'arde des seules excitations transmises par les fibres afférentes du nerf phrénqque

\section{ACKNOWLEDGMENTS}

I am grateful to the following surgeons for their patience and helpful cooperation in this investigation. Mr V. T Powell, Mr R Brooks' and the late Mr. D. A Langhorne, of Chichester, England, and to Dr C A McIntosh and Dr. D. D. Munro of Montreal.

\section{REFERENCES}

1 Bromage, P R. Spinal Epidural Analgesia Edinburgh - E. \& S. Livingstone (1954)

2 Bromage, P R. Hypotension and Vital Capacity. Anaesthesia 11139 (1956)

3 Foenster, O Dermatomes in Man Brain 56 1 (1933).

4 KEEGAN, J.J Relation of Nerve Roots to Abnormalities of Lumbar and Cervical Portions of the Spine Arch. Surg 55246 (1947)

5 KuRÉ, K Studies on the Dual Innervation of the Diaphragm with Special Reference to Tonus and Nutrition Amer. I Physiol 84.641 (1928). 
6. Botha, G. S. M. The Anatomy of Phrenc Nerve Termination and the Motor Innervation of the Diaphragm. Thorax 12: 50 (1957).

7. Keswani, N. H., \& Hollingshead, W. H. Localization of the Phrenic Nucleus in the Spinal Cord of Man. Anat. Rec. 125: 683 (1956).

8. Krause, W. Anatomische Vanetäten. Hanover: Hahn (1880).

9. Grozznitz, W. von (1901). Quoted by FeLIX, W., Deutsche Ztschr. f. Chir. 171: 283 (1922).

10. FeLrx, W. Anatomische, experimentelle und klinische Untersuchungen uber den Phrenicus und uber die Zwerchfellinnervation. Deutsche Ztschr. f. Chrr. 171: 283 (1922).

11. Hinsey, J. C., Hare, K., \& Phillips, R. A. Sensory Components of the Phrenuc Nerve of the Cat. Proc. Soc. Exper. Biol. \& Med. 41: 411 ( (939).

12. Drouet, P. L., Franck, C., Lamy, P., \& Arnould, P. Le Phrénique, nerf végétataf et nerf sensitıf. J. franç. méd, et chır. thorac. 8. 358 (1954).

13. Little, M. G. A., \& McSwiney, B. A. Afferent Fibres from the Diaphragm. J. Physiol 96: 2P (1938).

14. Cromer, S. P., \& Ivy, A. C. Respiratory Death from Central Vagus Stumulation after Removal of Stellate Ganglion. Amer. J. Physiol. 104: 457 (1933).

15. Craig, E. H. The Reflex Produced by Chemical Stumulation of the Deeper Respiratory Passages. Amer. J. Physiol. 59: 346 (1922)

16. Cromer, S. P., Young, R. H., \& Ivx, A. C. On the Exastence of Afferent Respuratcry Impulses Mediated by the Stellate Ganglion Amer. J. Physiol. 104: 468 (1933).

17. Wmoicomes, J G Respiratory Reflexes from the Trachea and Bronch of the Cat J. Physiol. 12355 (1954). 